\title{
GPS連続観测システムについて* \\ GPS Earth Observation Network System
}

\section{米溪武次 $* *$}

Takeji KOMETANI

\section{Key words GEONET,GPS}

\section{1.は じめに}

国土地理院は, 地殻変動の様相を把握するため, 明治以 来設置してきた三角点及び水準点などの標石基準点の定期 的な繰り返し測量や地震打よび火山活動の災害発生時の緊 急測量を行ってきた。これらの測量は, 現地作業を経て解 析結果を得るまでに数ヶ月から 1 年以上を要していた。 こ のような状況の中, 米国が 1973 年から軍事目的で開発し ていた精密宇宙測位技術の GPS (Global Positioning System : 汎地球測位システム) を民生用に解放すること, GPS が測量に利用でき連続監視が可能と思われることか ら，国土地理院は 1987 年に GPS 受信機を導入し, 精度の 評価や作業手法の確立のため研究作業を開始した. 1993 年, 米国はGPSの正式運用を開始. その後, 国土地理院 は GPS 観測局を電子基準点と名付け, 連続観測の自動化, 通信回線を利用した観測データの自動送信及び中央局での 解析処理を行う一連のシステムを確立し運用を開始した。 2005 年 4 月現在, 1229 点の電子基準点を全国に整備し (図 1), GPS 連続観測システム（GEONET：GPS Earth Observation Network System) として管理・運用を行っ ている. 電子基準点で得られた成果は各種測量の基準とし て利用されるほか, 日々の解析結果は, 地震調查研究や火 山噴火予知研究のための広域地殼変動監視に利用してい る. 当該年度の観測データや解析結果は, 国土地理院ホー ムページからユーザに提供している. 電子基準点で取得し ているリアルタイムデータは, 配信機関を通じて位置サー ビス事業者に向けて提供している.

本稿では，GPS 連続観測システム（GEONET）の概要 について報告する．

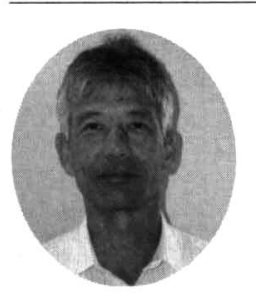

*原稿受付 平成 17 年 8 月 30 日

**国土地理院 (茨城県つくば市北唧 1 番)

米溪武次

昭和 46 年 建設省国土地理院

昭和 47 年 建設大学校 終了

昭和 60 年 第 27 次南極地域観測隊 (夏隊) 隊員

平成 16 年 測地観測センター衛星測地課長補佐

著書 改定新版 絵で見る地籍測量（共著）

\section{GPS 連続観測システム（GEONET）について}

GEONET は，全国に約 $20 \mathrm{~km}$ 間隔で設置している 1229 点の電子基準点で構成される GPS 観測ネットワークと, 観 測データを集約・解析処理をして座標值を算出する国土地 理院中央局の管理・解析システムから構成されている ${ }^{1)}$.

ほとんどの電子基準点では，GPS 信号を 1 秒ごとに受 信し常時接続回線（IP-VPN）でリアルタイムに国土地理 院中央局に転送している. 離島及び高山地域の一部の電子 基準点は ISDN 回線および衛星携帯通信を利用している.

中央局は, リアルタイムデータ通信管理装置, データ通 信管理装置, 電子基準点管理制御装置, データ格納装置, 定常解析処理装置, リアルタイムデータ解析処理装置, 解 析結果表示装置などで構成されている。これらの装置で電 子基準点からリアルタイムに送信してくるデータの制御・ 管理から解析などの一連のデータ処理を行っている.

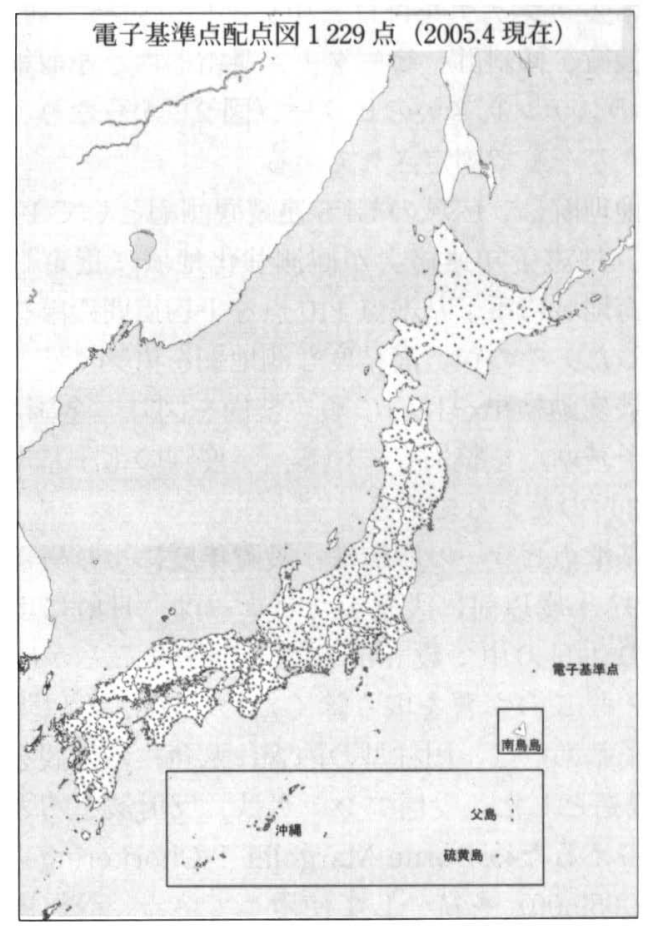

図1 電子基準点配点図 


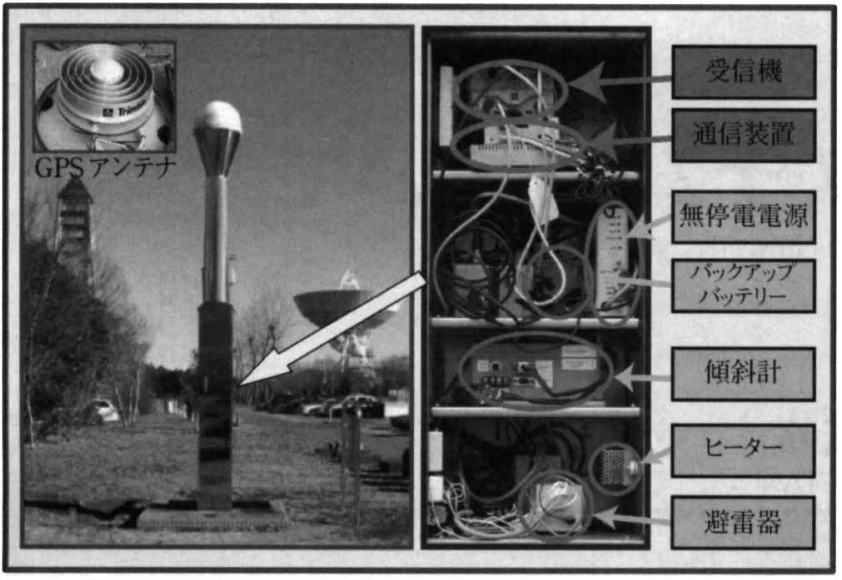

図2 電子基準点
表 1 電子基準点設置一覧

\begin{tabular}{c|c|c}
\hline 設置年度 & 点数 & 設置範囲 \\
\hline $1993(\mathrm{H} 5)$ & 110 & 南関東·東海 \\
\hline $1994(\mathrm{H} 6)$ & 100 & 全国 $($ 上記除く) \\
\hline $1995(\mathrm{H} 7)$ & 400 & 全国 \\
\hline $1996(\mathrm{H} 8)$ & 277 & 全国 \\
\hline $1997(\mathrm{H} 9)$ & 60 & 全国 \\
\hline $2002(\mathrm{H} 14)$ & 253 & 全国 \\
\hline $2003(\mathrm{H} 15)$ & 24 & 東南海・南海 \\
\hline $2004(\mathrm{H} 16)$ & 5 & 東南海·南海 \\
\hline 計 & 1229 & \\
\hline
\end{tabular}

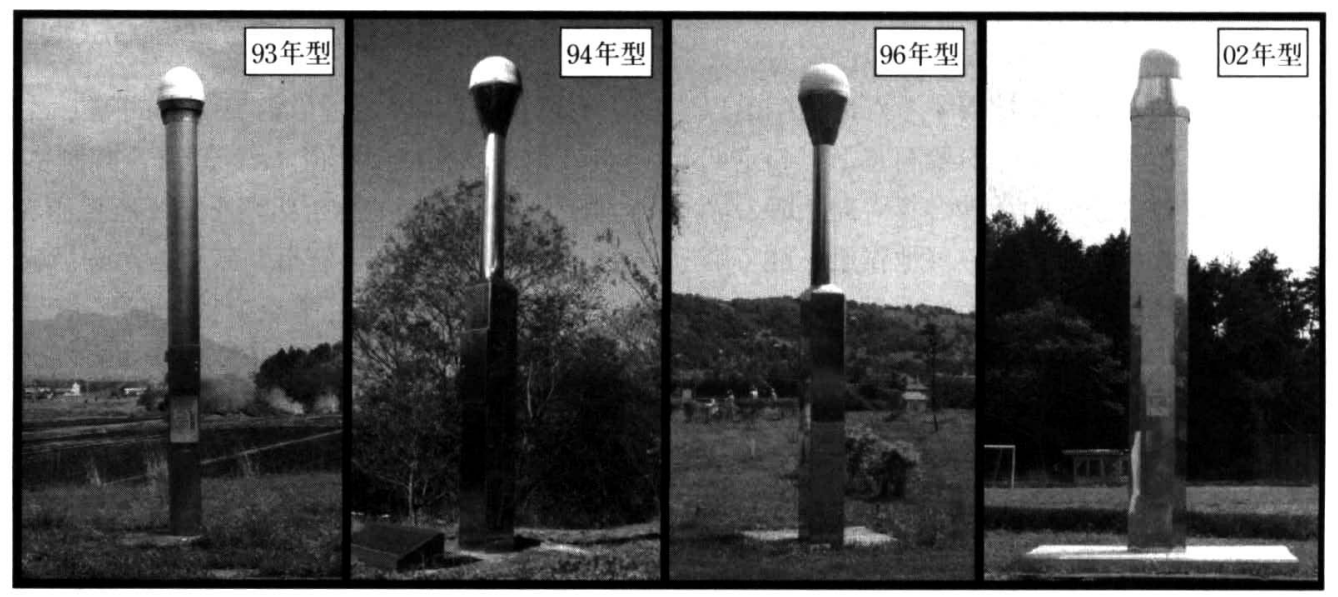

図 3 電子基準点の形状

\section{1 電子基準点}

電子基準点は, 頂上レドーム内に GPS 衛星からの信号 を受信するアンテナを付け, 中央部に受信機, 通信機器, 無停電装置, 傾斜計, ヒーター, 避雷器などを収納した高 さ $5 \mathrm{~m}$ のステンレス製のピラー（図 2）からなり，基礎部 はコンクリートで固定されている.

国土地理院は, 広域の GPS 連続観測網として 1993 年度 初めて, 地震予知連絡会が観測強化地域に選定した南関 東・東海地域に電子基準点 110 点を平均点間距離約 $15 \mathrm{~km}$ で設置した。その後, 高精度な測地網を構築するとともに 広域地殼变動検出を目的に順次整備を図り, 全国に 1229 点の電子基準点を整備している. 年度別の電子基準点設置 は（表 1）のとおりである.

電子基準点ピラーの形状は, 設置年度により異なる（図 3). 1997 年度以前に設置したピラーは, 日射による熱膨 張により 1 日の中で数 $\mathrm{mm}$ 程度変動することが確認され ていた ${ }^{2)}$.この影響を取り除くため, 2002 年以降に設置 した電子基準点は, 円柱型の内管に八角柱の外観を配した 2 重管構造とした。受信アンテナは, 反射波を防ぎ位相特 性をそろえるため Dorne Margolin T Chorkering Antenna (TRM29659.00) を統一して使用している。受信機は, 長 期の通信トラブルの際のリカバリーのため大容量メモリー
を装備しているほか, 停電時にデータを遮断なく取得する ため全点で 6 時間の無停電対応バッテリーを装備してい る. さらに南関東・東海地域及び東南海・南海地域, 三宅 島および中越地方の点については通信機器にも 6 時間から 72 時間対応の無停電対応バッテリーを装備し停電時にデー タの送信が可能となっている.

地震動や火山噴火によるピラーの傾斜をチェックするた め傾斜計を設置している. 南北・東西方向の傾斜量データ が GPS 観測データとともに中央局に転送されている. 落 雷, 誘導雷, 接地雷から各機器を保護するために, アンテ ナに同軸避雷器さらに電源部及び通信部に避雷器を設置し ている.

\subsection{GEONET の中央局解析処理システム}

国土地理院は, 2002 年度にデータ処理システムを改造 した。短時間でのスタティック解析やリアルタイム解析を GEONET の解析機能に取り入れることで, より高速な地 殻変動情報の把握が可能となった. GEONET 中央局での データ処理システムは, 大きく次の部分に分けられる. GEONET システムの概念挧は（図4）のとおりである。

（1）リアルタイムデータ通信管理装置

常時接続化済み電子基準点からのリアルタイムデータを 受け取り生データの状態で一時保存するとともに，1時間 


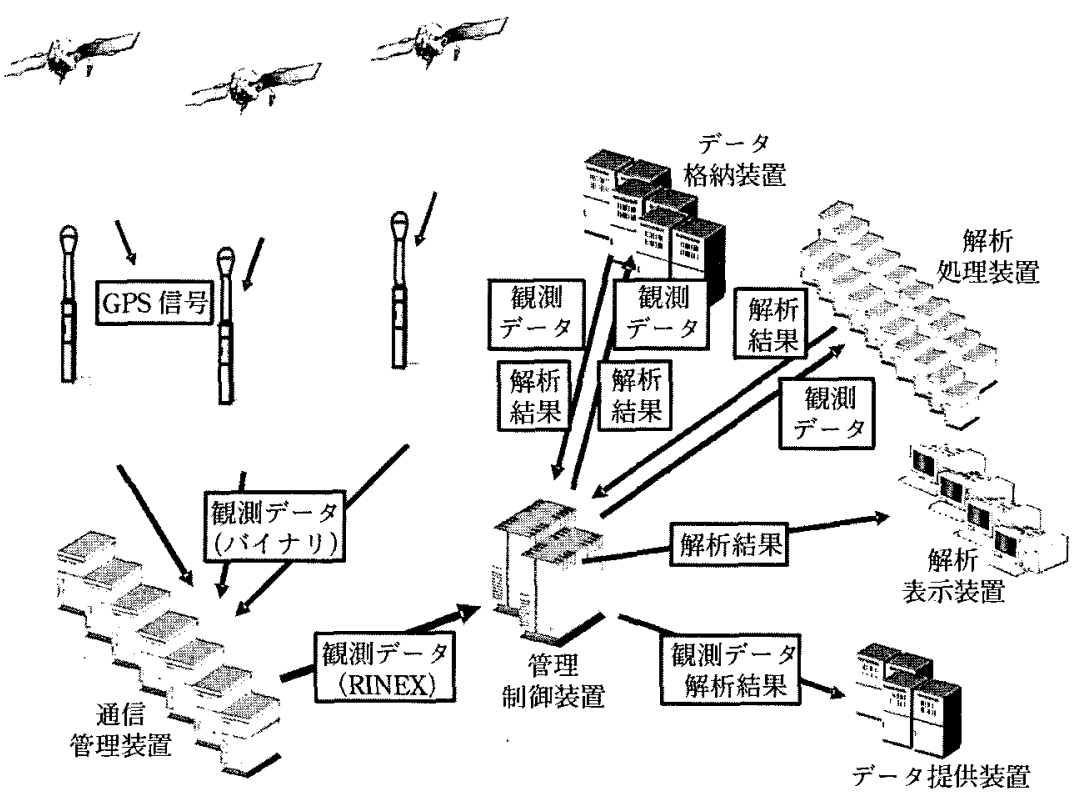

图 4 GEONET システム概念図

ごとにRINEX形式*1のファイルを作成し，データ格納装 置に送る。このとき，サンプリング間隔は 1 秒から 30 秒 に間引きされる。また，必要に応じ RTCM形式*2のリア ルタイムデータをリアルタイムデータ解析処理装置に送信 する.

（2）データ通信管理装置

常時接続化されない電子基準点からのデータを受け取る 部分である。基本的にリアルタイムデータ通信管理装置と 同一の機能を備えているが，リアルタイム処理に係る作業 のみ行わない、なお，ダウンロードを 3 時間ごとに行う制 約から RINEX 変換を行う時間間隔は 1 時間ではなく 3 時 間になっている。

（3）電子基準点管理制御装置

データ処理システムの自動運用管理, 電子基準点制御, 電子基準点データベースの管理を行う。

・自動運用管理機能：RINEX ファイルの結合扎よび品質 検査, 定常解析の設定・スタート，ファイルの送信や格納 などを予め定められたスケジュールに従い自動的に行う。 ・電子基準点制御機能：受信機のデータダウンロードや観 測開始・終了などの制御を遠隔操作により行う。

・データベース管理機能：電子基準点データを管理する上 で必要となる情報を一元管理する，具体的には，電子基 準点名や所在などおよびその履歴, 各種ファイルの格納 先, 解析設定と解析結果, 電子基準点保守情報などが含 まれる。

(4) データ格納装置

電子基準点からの RINEX データや解析に使われる必要 なファイル, 解析結果ファイルなどを保存する。ここでは, リアルタイムデータ通信管理装置から送られた 1 時間ごと の RINEX ファイルを 3 時間ごとに結合し 1 ファイルとし て保存しているが, 最終的には1日1ファイルで管理し，
CD-R な゙のメディアにバックアップを行う.

（5）定常解析処理装置

Bernese/BPE をコアソフト*3 とする定常解析を行う。 この装置は20台のPC（OSは Linux）で構成され, 基線 解析*4 部分の処理をクラスタごとに分割処理して高速化 を図っている。多様化する解析の需要に合わせ 1 式当たり 6 プロセスの解析を独立して起動できる.

(6) リアルタイムデータ解析処理装置

緊急時に, 最大 50 点の電子基準点を対象としたリアル タイム解析を行う。後処理での実行も可能となっている.

(7) 解析結果表示装置

定常解析及びリアルタイム解析結果をグラフ化し, 編集 する部分である。この装置は, 用途に応じてさらに 4 つの 装置に細分化される。

・定常解析結果表示装置：データ格納装置から解析結果の 転送を受け，定常解析結果の情報を集約管理するほか， 外部情報提供装置と地殻情報管理装置にも転送する. 得 られた解析結果は，專用の表示プログラムを利用してグ ラフ化することができる。

・リアルタイム解析結果表示装置：リアルタイムデータ解 析処理装置が行うリアルタイム解析の結果をリアルタイ ムに転送を受けて表示する。

・外部情報提供装置：ユーザがインターネットを通じて閲 覧できるように定常解析結果に基づく観測局の変動情報 を生成する。

\footnotetext{
*1 RINEX (Receiver Independent Exchange) は, 異なるGPS受信機,ソフト ウェア会社間の GPS データの交換のために使用される標潐フォーマット

*2 RTCM (The Radio Technical Commission for Maritime Services : 米国海 上電波技術委員会）は，特別委員会 104 に引いて定めた GPS データの 誤差補正量, 座標值などの各データの祭準フォーマット

*3 Bernese/BPE は，一連の GPS 解析を定常的に自動で行うンフトウェア *4 観測点間の幾何学的な位圆関係を求める計算を基線解析という.
} 
表 2 GEONETで実施している解析の種類

\begin{tabular}{c|c|c|c|c}
\hline 解析の種類 & ID & 曆 & セッション長 & 頻度 \\
\hline 最終解析 & F2 & IGS 最終暦 & 24 時間 & $\begin{array}{c}1 \text { 週間分を } \\
1 \text { 週間ごと }\end{array}$ \\
\hline 速報解析 & R2 & IGS 超高速暦 & 24 時間 & 1 日ごと \\
\hline 迅速解析 & Q2 & IGS 超高速暦 & 6 時間 & 3 時間ごと \\
\hline 緊急解析 & S2 & IGS 超高速暦 & $\begin{array}{c}1 \text { 時間単位で } \\
\text { 任意 }\end{array}$ & $\begin{array}{c}1 \text { 時間単位 } \\
\text { で任意 }\end{array}$ \\
\hline リアルタイム & - & IGS 超高速暦 & 1 秒 & 任意 \\
\hline
\end{tabular}

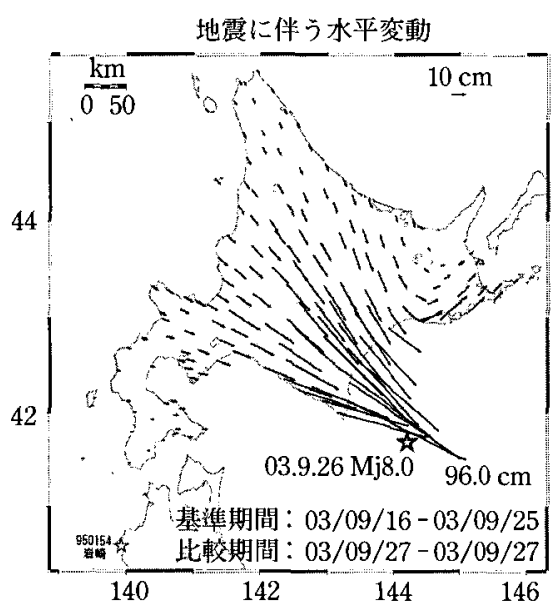

標準偏差值 $(\mathrm{mm})$
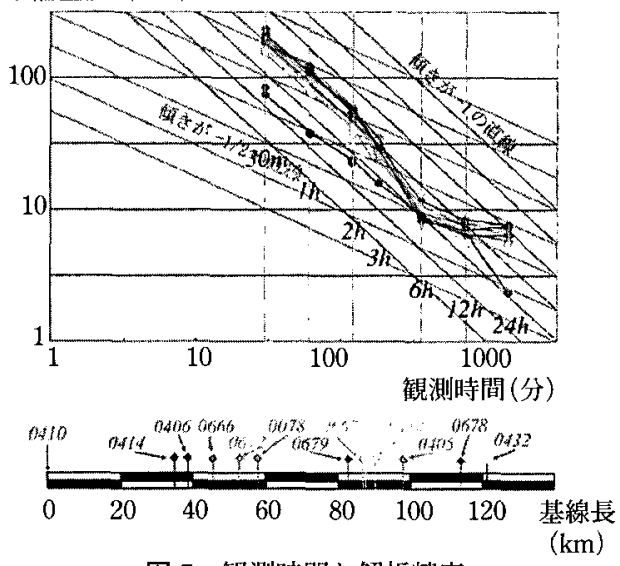

图 5 観測時間と解析精度

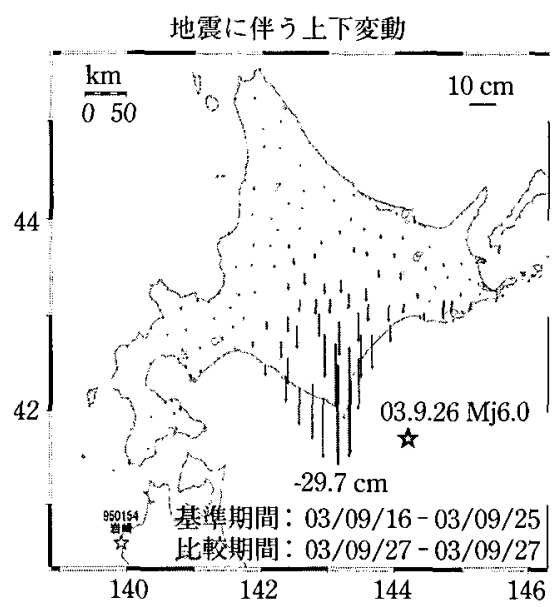

図 6 地震に伴う水平・上下運動

・地殻情報管理装置：各種資料作成用に解析結果やグラフ などを表示編集する。

\section{GEONET での解析}

GEONETでは，需要に応じて多様な解析を夹施してい る（表 2). 全点を対象とする定常解析は，最終解析 (F2)， 速報解析（R2），迅速解析（Q2）の3 種類であり，この他， 緊急時には緊急解析（S2）を行うことができる。記号はそ れぞれ Final, Rapid, Quick, Special の頭文字である. 4 者の解析に使用するモデルは基本的に同一で，異なるのは 使用する暦，セッション時間，および解析頻度である．F2 はIGS (International GNSS Service) *5 最終暦を R2，Q2 および S2 は IGS 超高速暦を用いている．IGS 超高速暦は 前半が速報暦, 後半が予測暦であるが, 予測暦は軌道変更 などには対応できず，予測が大きくはずれる場合があるの で，軌道情報の品質をチェックして使用する，Q2 は 6 時 間のデータウインドウを 3 時間ずつずらしながら準リアル タイムで解析を奏施している。これは，GEONETのデー タがリアルタイムで転送される体制が整ったことにより可 能になったものである。

\section{4. 観測時間と解析精度}

地震および火山活動が活発化したとき地殻変動の様相を
より早く把握するためには，1セッションあたりの観測時 間を短縮するのが望ましいが，その場合解析精度の低下は 避けられない。この観測時間と解析精度とのトレードオフ の関係を示したのが（図 5）である 1)。この図から，観測 時間と標準偏差との間に相関が見られ，観測時間が 24 時 間であれば， $1 \sigma=10 \mathrm{~mm}$ 未満の標準偏差で解析結果が得 られることや 6 時間未満の観測データによる解析を行った 場合，統計的に妥当とみなされる以上の精度少化が生じる ということがわかる。準リアルタイムの迅速解析（Q2） のセッション長を 6 時間としたのはこのためである.

\section{GEONET が捉えた地款変動検出}

GEONET により得られたコサイスミックな地壳変動は， 地震予知連絡会や国土地理院 HP などで一般に公表し GPS 連続観測システムの即応性を明らかにした。有珠山や三宅 島の火山活動，鳥取県西部地震などの地壳変動を迅速かつ 従来にない高い精度で捉えている。本項では，GEONET

*5IGS では, 測地学・地球物理学等の研究活動支援を目的とし各国関係機 関の協力のもと，全世界にGPS 衛星の追跡ネットワークを满筑し連続 観測を行っている。観測データは，アメリカとフランスにあるデータセン ターで集中管理し提供している. データセンターでは, 観測データから GPS の軌道楿，地球回転パラメーターなどを生成し公開している。軌道暦と は人工衛星の運動を時系列で表したもので生成の迅速さと䊑度により最 終暦，超高速暦等がある. IGS が提供しているこれらを IGS 暦という。 


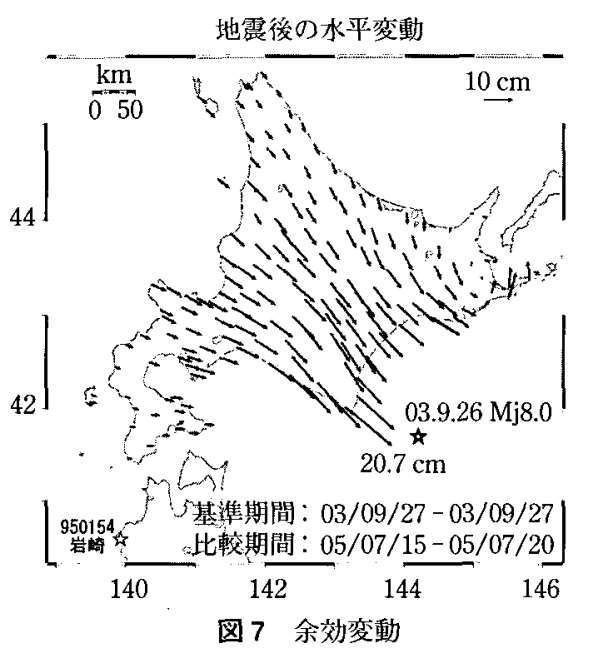

が捉えた最近の地壳变動の解析結果を紹介する.

\subsection{3 年十勝沖地震}

2003 年 9 月 26 日 4 時 50 分頃に北海道十勝沖を震源と する震度 6 弱 $(M$ 8.0) の地震が発生し, 北海道の広い範 囲で地㪍変動を検出した。震源に近い襟裳岬周辺で変動が 大きく，青森県の「岩崎」を固定として見た場合，「穴尾」 が最大で南東方向に約 $96 \mathrm{~cm}$ 移動し，「大樹 $2 」 て ゙$ 約 $30 \mathrm{~cm}$ の沈降がみられた（図6）。これは，GEONETの運用開始 以来, 水平・上下方向とも最大の変動量であった。

大地震が発生すると，その後に生じるゆっくりとした地壳 変動がしばらく続くことがある。このような現象を余効変 動と呼んでいる. 今回の地震で襟裳岬付近を中心に北海道 の広い範囲で余効変動が観測されており，地震後から 2005 年 7 月までに「えりも $1 」$ で南東方向に約 $21 \mathrm{~cm}$ の水 平変動が確認されている(図 7).

\subsection{4 年新潟県中越地震}

2004 年 10 月 23 日 17 時 56 分頃新潟県中越地方を震源 とする最大震度 7 の地震（M 6.8）が発生し, 新鼬県を中 心とする広い範囲で地款変動を検出した。「守門」が約 21 $\mathrm{cm}$ 北西方向へ移動し,「小千谷」で約 $26 \mathrm{~cm}$ の隆起が見ら 机た（図 8).

\section{6. おわりに}

衛星測位システムの GPS を利用した GEONET の整備に より, 日本列島の地殻変動の監視および把握が従来に比べ きわめて迅速かつ詳細に把握されるようになった。

衛星測位システムは米国の GPS 近代化政策，欧州共同
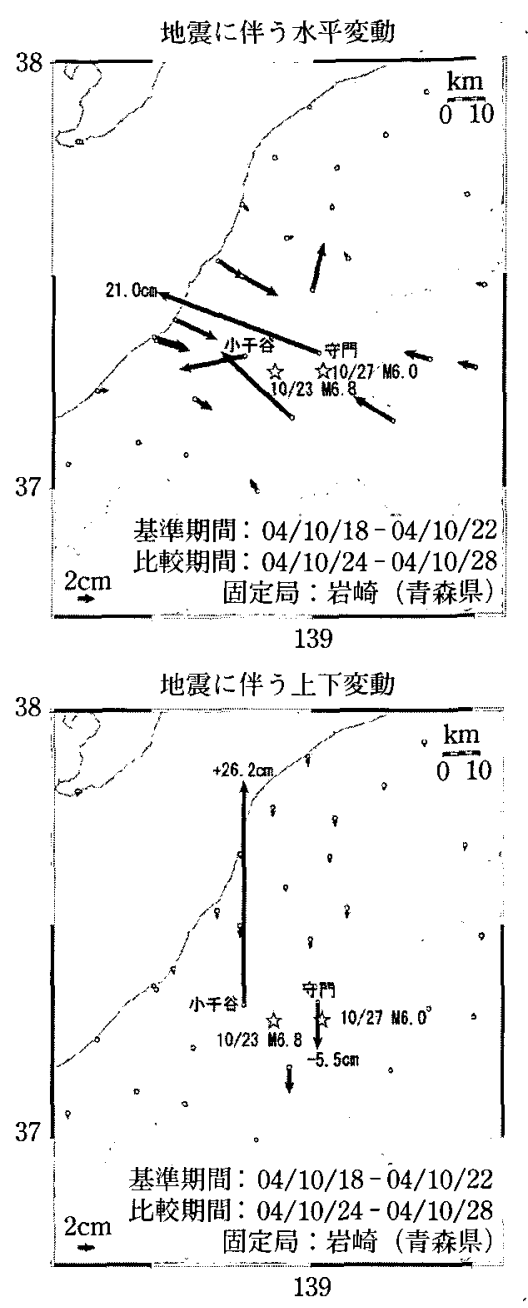

図 8 地震に伴う水平・上下変動

体による GALILEO の構築，ロシアによる GLONASS の改 良，我が国に打付る準天頂衛星計画など，次世代衛星シス テムの開発計画が進められており新たな発展期に入りつつ ある.GEONETもこれらの動向を踏まえ，更に高精度で 安定したシステムへの高度化を図ることにより即時性の高 い地殸変動の監視が実現し防災，減災に向けた情報提供の ッールとして重要な役割を担うものと期待される。

\section{参 考 文 献}

1）測地観测センター: 電子基準点 1,200 点の全国整備について, 国土 地理院時報, 103 集, (2004).

2）阿部 警, 菊田有希枝, 堀田暁子, 堀弘, 营富美男, 田村 孝, 藤咲淳一, 大滝 修, 日下正明, 畑中雄樹, 石原 操: 電子基準点の 日照変位, 日本測地学会誌, 92 (1999) 